\title{
"Write (Right) the World": The benefits of publishing in Te Kaharoa: The eJournal on Indigenous Pacific Issues for Master of Applied Indigenous Knowledge students, 2018-2019
}

\section{Introduction}

Since my arrival at Te Wānanga o Aotearoa in mid2017, I have taught students the importance of "writing/righting the world" through publishing. Over 2018-2019, I worked with eleven Master of Applied Indigenous Knowledge students from Te Wānanga o Aotearoa who published a total of 18 articles-centred on their postgraduate work-in Te Kaharoa: The eJournal on Indigenous Pacific Issues, based at Auckland University of Technology. This paper will argue that publishing in a peer-reviewed journal generated benefits for Indigenous communities and themselves. In 2019, I interviewed seven of these students to find out what particular benefits they believed had come out of the publishing experience. First, this paper will outline the Master of Applied Indigenous Knowledge programme; additionally, I will reflect briefly on my experience teaching the master's since mid-2017. Second, this paper will identify the general benefits of student publishing. Third, this paper will display the interview questions and student responses, and using thematic analysis, this paper will identify the themes that 
emerged from the interviews. Last, this paper will identify the particular benefits that were experienced by the students from their publishing efforts.

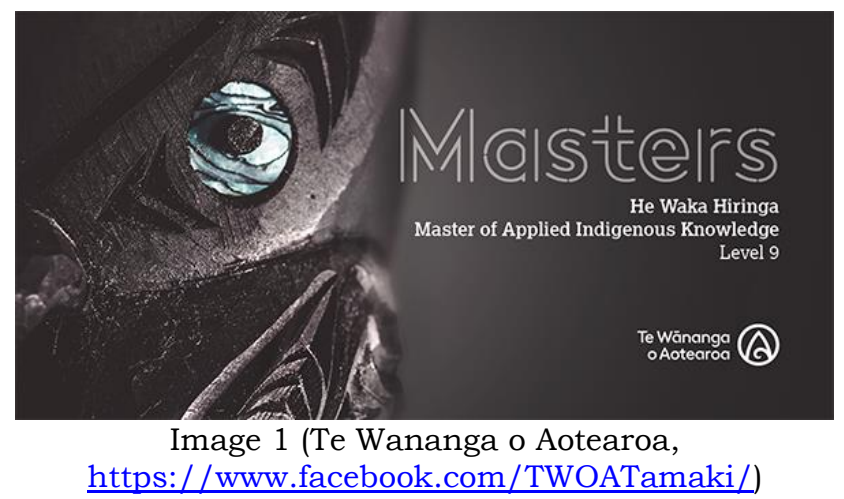

\section{Master of Applied Indigenous Knowledge degree, Te Wānanga o Aotearoa}

The Master of Applied Indigenous Knowledge is a programme that recognises the expertise of Indigenous practitioners in particular fields of knowledge and guides them through the process of writing a 15,00020,000-word exegesis and completing a practice and research-based project that contributes to the development of their Indigenous communities.

As part of the programme's outcomes, the programme aims to empower graduates to demonstrate the following:

- Show evidence of advanced knowing in a specialist area of Indigenous Knowledge

- Understand and apply sophisticated theoretical knowledge including Māori principles and philosophies ( or other indigenous equivalent ) 
- Critically evaluate the findings and discussions form relevant literature and life experience

- Rangahau, analyse and wānanga from evidence

- Independently self-reflect on all aspects of learning and practice

- Transfer and apply knowledge to new situations

- Engage in rigorous intellectual analysis, critique, and problem solving

- Contribute to an indigenous community through completion of a community based project; provide leadership with a specific field, and modelling of principle based practice

- Pursue lifelong learning, either community based or at a doctoral level within a field of indigenous knowledge

- Pursue individual excellence for collective success, generating a holistic methodology (Te Wānanga o Aotearoa, 2019, p. 8).

The Master of Applied Indigenous Knowledge is comprised of five papers known as kōnae ako. There are four papers in the first year and one paper in the second and final year. The kōnae ako are as follows:

\section{Mōhiotanga-Experience and Knowledge Production (year one)}

In this kōnae ako tauira will explore the nature of knowledge (epistemology) and critically evaluate the way that tacit knowledge (knowing gained through direct experience) influences practice. Tauira will examine the intergenerational transfer of traditional knowledge and the preservation of Indigenous ways of knowing and will position themselves as Indigenous practitioners within their specialised field of practice. At the completion of this kōnae ako, tauira will develop and present a holistic model of understanding that reflects their practice (Te Wānanga o Aotearoa, 2019, p. 12) 


\section{Mātauranga-Thought and Knowledge Production (year one)}

In this kōnae ako, tauira will deconstruct their practice with reference to underlying Māori/ Indigenous principles and values, and compare and contrast these with other Indigenous practitioners. Tauira will critically evaluate a range of Indigenous models / frameworks related to Indigenous thought reification and develop their own distinctive principle based model of practice (Te Wānanga o Aotearoa, 2019, p. 23).

\section{Māramatanga-Wisdom and Knowledge Production (year one)}

This kōnae ako will provide tauira with the skills and knowledge to formulate and interpret values and ideas of knowledge through philosophical inquiry. Tauira will explore philosophy with the intent of critiquing ethical issues, logic and debates about the nature of indigeneity. In this kōnae ako, tauira will synthesise information from literary, oral and/or visual sources to support a Māori /Indigenous philosophical position that relates to field of practice (Te Wānanga o Aotearoa, 2019, p. 34).

\section{Mauri Ora-Well-being, Knowing and Transformation (year one)}

In this kōnae ako, tauira will design an Indigenous community-based rangahau project that will be implemented in Kōnae Ako 5. This kōnae focuses on specific aspects of Indigenous rangahau design including the selection of a relevant rangahau topic; constructing pertinent rangahau questions, identifying appropriate rangahau approaches and outlining the tikanga rangahau (ethical) considerations associated with Indigenous rangahau. Tauira will develop a Kaupapa Proposal and complete a Tikanga Rangahau (ethics) application as part of this kōnae ako (Te Wānanga o Aotearoa, 2019, p. 43). 


\section{Maumaharatanga-Applied Indigenous Knowledge Project and Exegesis (year two)}

This kōnae ako is the pinnacle of tauira knowledge and practices in He Waka Hiringa: Master of Applied Indigenous Knowledge. It provides the vehicle to apply and evaluate learning within the context of an applied project connected to indigenous epistemology and an indigenous community. At the end of the konae, tauira will present their taonga tuku iho and communicate the findings of their projects. Tauira will also produce a written report (an exegesis) as part of this final kōnae ako (Te Wānanga o Aotearoa, 2019, p. 53).

I have taught the Master of Applied Indigenous Knowledge programme in Auckland since mid-2017. The experience has been utterly enlightening. Our master's is an "amazing" course to teach. The word amazing is often overused. Amazing can mean astonishing, astounding, surprising, bewildering, stunning, staggering, shocking, startling, stupefying, breath taking, perplexing, confounding, dismaying, disconcerting, shattering, awesome, awe-inspiring, sensational, remarkable, spectacular, stupendous, phenomenal, prodigious, extraordinary, incredible etc.

The Master of Applied Indigenous Knowledge is a truly amazing course to teach for the abovementioned reasons and more. As a kaiako of this master's programme, I am constantly and consistently blown away by the work of our students. In the 2018-2019 cohort we had students from diverse backgrounds including Māori, Sudanese, Sāmoan, Ghanaian, Tongan, Chinese, Niuean, and Cook Islands Māori. Each student brings with them their tacit knowledge that emerges from their whakapapa/genealogy, their lived experiences, and their respective indigenous practices.

In my experience in mainstream education, master's degrees tend to be about demonstrating mastery as a researcher. In general, the university tells master's students they do not know anything until they achieve a 
doctorate and become an "expert" in a particular field of knowledge. However, our master's students come to us as Indigenous practitioners and experts in their respective fields with $10+$ years of relevant experience. Our mission is to empower our students to expand and extend their respective practices in ways that further benefit their communities through the implementation of a research-based community project and a 1520,000-word exegesis.

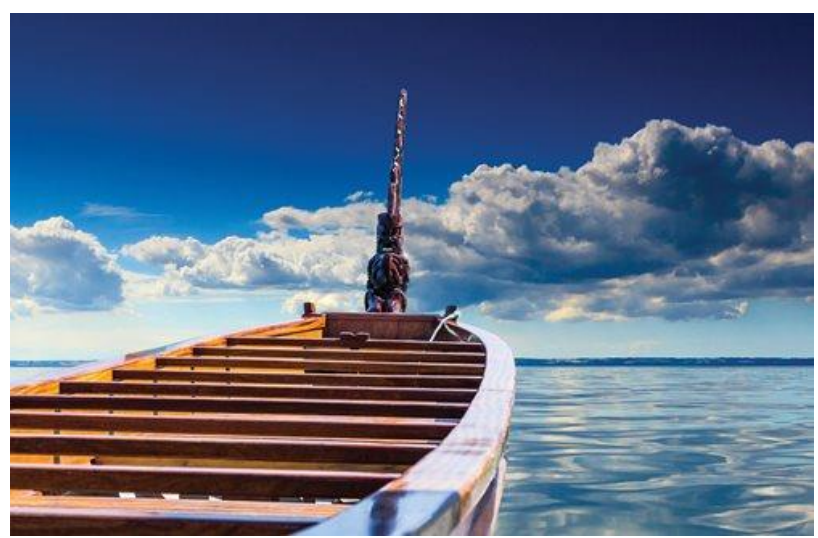

Image 2 (from Cooper's article on He Waka Hiringa, Cooper 2016, n.p.)

In the Master of Applied Indigenous Knowledge programme, we expect students to develop new and innovative research-based projects that contribute significantly and specifically to their communities and to Indigenous knowledge more broadly. This master's degree is informed by the hearts and minds of our students and their communities. Indeed, our students look out to the horizon and navigate themselves and their communities to explore beyond what is already known and seen. 


\section{The benefits of publishing for students}

Nackoney, Munn and Fernandez (2011) argued that some of the common obstacles for graduate student publishing includes a lack of guidance, feelings of inadequacy, sensitivity to critical feedback, and issues concerning time management. However, the once these hurdles are overcome-in my experience this is achieved by direct supervision and encouragement-there are a range of benefits for students that come out of publishing their work.

Kamler (2008), Lee and Kamler (2008), and Macauley and Green (2007), opined that student publishing is beneficial to students, supervisors, institutions and communities. Preacher (2003) wrote that publishing work, as a graduate student is beneficial because it gives an emerging researcher the opportunity to contribute to a field of study. Similarly, Van Cott (2005) argued that it is important for graduate students to publish as early as possible in their academic careers: "Students who start thinking about publishing from the get go, and who take advantage of the resources available, should be able to place some of their work in scholarly journals" (p. 741). Rich (2013) also contended that graduate students should plan early to publish their work which can give them an edge with regard to a future career in academia. Indeed, Pickering and Byrne (2013) argued that through the publishing process students experienced "an increased sense of achievement during the course of their study and improved motivation in progressing to the next stage of their research" (p. 535).

Trammell (2014) identified a number of benefits for student writers:

- Improves writing and research skills:

Researching, writing, editing and publishing work for the first time exposes a student to 
valuable feedback which will inform future writing;

- Exposes students to the scholarly publication process: Exposure to the scholarly publication process familiarises students with what is required;

- Connects students to researchers: Students are connected to academic staff in ways that are not typically experienced in the classroom; publications may be read by other academics, nationally and internationally, thereby creating new connections and the potential for future collaboration;

- Displays leadership and initiative: The publication process is hard work; faculties, employers, and graduate schools should recognise the level of effort needed to publish as evidence of leadership and initiative;

- Professionalises the student experience: The publishing of a paper provides a level of professionalisation to the students Curriculum Vitae;

- Informs a future career path: The publishing of a paper may inform a future career path and highlight opportunities that may otherwise have not been contemplated before.

Collins (2015) asserted that in the academia, graduate students are not generally considered experts in their field of knowledge until they achieve a doctorate. However, with regard to doctorates, Collins (2015) argued that most cannot claim to know everything about their field: "At best, many probably knew close to everything about their dissertation topic at one point in time, but it is likely that new findings and information with which they are unfamiliar have emerged since that time" (p. 54). Collins (2015) stated too that not knowing everything about a field of knowledge does not mean that one cannot write authoritatively about a topic: "The 
best writers know how to make the most of what they know, identify gaps in knowledge, and work to fill those gaps" (p. 54). Indeed, Collins (2015) opined that graduate student writers should see themselves as authorities of their work as "[b]eing a skilled writer is about understanding the topic of concern enough to convey the meaning and importance behind what you have to say" (p. 54).

\section{Interview questions}

Students were asked the following questions about their experiences of publishing:

- How did you feel about being asked to publish a paper?

- What would you like to share about the experience of preparing a paper for publication?

- What was your process for converting your master's paper into a paper for publication?

- What support did you receive from your kaiako?

- What further support could have been provided?

- How did you feel when your paper was published?

- What do you think are the benefits of publishing for He Waka Hiringa students?

- What benefits have you experienced so far from publishing?

- Would you publish again and why? Or why not?

\section{Student responses}

I interviewed seven out of the eleven students that published in 2018-2019. The students interviewed were: William Cuthers, Daena Walker, Rosalie Leuluai, Latoia Sasa-Tepania, Kane Milne, Fritz Filisi and Vania Hotereni. The following section contains their responses to each question and a Word Cloud diagram. Word Clouds are visual representations of text data. The more frequently a word is used, the more prominence it has in 
a Word Cloud diagram. Word Clouds are used in this article to illustrate the words most frequently used in the responses. Indeed, I have followed Milne's (2019) example-in Explorations of the term 'Indigenous'-of using Word Clouds in academic writing.

\section{William Cuthers}

1) How did you feel about being asked to publish a paper?

"I felt as if my lecturer, Dr Rangiwai, saw potential in me. I felt motivated as if my lecturer saw I had something to offer. I felt as if I could do it" (W. Cuthers, personal communication, 2 October 2019).

\section{2) What would you like to share about the experience of preparing a paper for publication?}

"I wasn't too worried in the preparation period for publication; I was more concerned about how that publication would be received when peer reviewed and if I was good enough to be published" (W. Cuthers, personal communication, 2 October 2019).

3) What was your process for converting your master's paper into a paper for publication?

"I had a few changes to make in my master's work but it wasn't too major" (W. Cuthers, personal communication, 2 October 2019).

\section{4) What support did you receive from your kaiako?}

"Dr Rangiwai was the drive behind publication. He pushed his students to produce publishable academic writing" (W. Cuthers, personal communication, 2 October 2019).

5) What further support could have been provided? 
"Dr Rangiwai provided a lot of opportunities and it was really up to me to identify those opportunities and seize them" (W. Cuthers, personal communication, 2 October 2019)

\section{6) How did you feel when your paper was published?}

Having published literature is an achievement. I had dreams of publishing work in the future but never thought that it would happen in the first year of my master's degree. Seeing my own work published also strengthened my own self-belief and enhanced my confidence, not just in relation to my master's work, but across the board (W. Cuthers, personal communication, 2 October 2019).

7) What do you think are the benefits of publishing for He Waka Hiringa students?

Enhanced self-belief was a definite benefit. To see my own work published was like making history. When I saw I could make history in terms of a published article, I really felt that I could do a lot more than that. If I put my mind and effort to something, I could change history again (W. Cuthers, personal communication, 2 October 2019).

\section{8) What benefits have you experienced so far from publishing?}

My confidence has been enhanced. I feel as if I matured intellectually. As a result of publications I was asked to guest lecture at the University of Auckland and the University of Waikato. My published work has been included as course reading in a paper at the University of Auckland. My writing skills have improved exponentially. Publishing was a transformational experience that changed my life for the better on a number of levels (W. Cuthers, personal communication, 2 October 2019). 


\section{9) Would you publish again and why? Or why not?}

"For sure. I feel that we need more of our stories in the mainstream and an effective way to accomplish this is through publications" (W. Cuthers, personal communication, 2 October 2019).

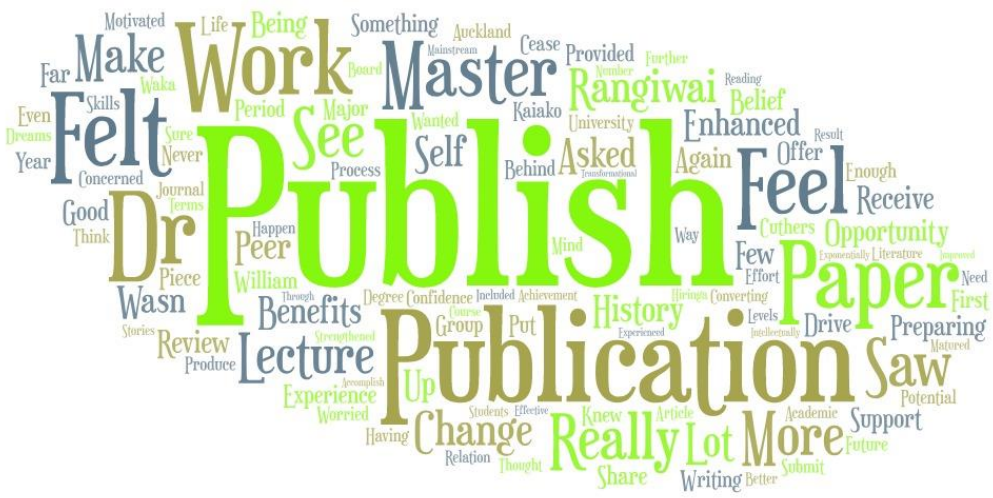

Image 3: Word Cloud based on William Cuthers' interview

\section{Daena Walker}

1) How did you feel about being asked to publish a paper?

When Dr Rangiwai asked me to publish, I was nervous because I had never presented my writing to a public forum, let alone an academic forum. The whole process made me feel nervous and anxious, and I almost changed my mind to not submit my paper at the last minute (D. Walker, personal communication, 2 October 2019).

2) What would you like to share about the experience of preparing a paper for publication? 
"Nerve-wracking! I recommend having your work edited and checked before submitting your final drafts" (D. Walker, personal communication, 2 October 2019).

\section{3) What was your process for converting your} master's paper into a paper for publication?

"Dr Rangiwai was instrumental because he checked my work and discussed feedback with me" (D. Walker, personal communication, 2 October 2019).

\section{4) What support did you receive from your}

\section{kaiako?}

My kaiako. Dr Rangiwai, has always encouraged me with my writing. Dr Rangiwai provided me with critical feedback that was constructive and useful, especially with regard to research and planning around my workload. Dr Rangiwai provided our tauira with consistent encouragement to achieve our writing goals (D. Walker, personal communication, 2 October 2019).

\section{5) What further support could have been provided?}

"I felt that I received ample support for my mahi" (D. Walker, personal communication, 2 October 2019).

\section{6) How did you feel when your paper was} published?

"I was relieved that it was accepted, peer-reviewed, and published by the journal" (D. Walker, personal communication, 2 October 2019).

\section{7) What do you think are the benefits of publishing for He Waka Hiringa students?}

Our published works will assist future tauira and hopefully provide them with the confidence to write and publish their own work. Our written work also provide mātauranga for other students to learn from, which 
increases the overall knowledge available to them (D. Walker, personal communication, 2 October 2019).

\section{8) What benefits have you experienced so far} from publishing?

"Publishing my paper has given me confidence and courage to continue writing and publish more of my work in the future" (D. Walker, personal communication, 2 October 2019).

\section{9) Would you publish again and why? Or why not?}

"Yes. I believe it is essential to increase the Te Ao Māori knowledge base and share this with others" (D. Walker, personal communication, 2 October 2019).

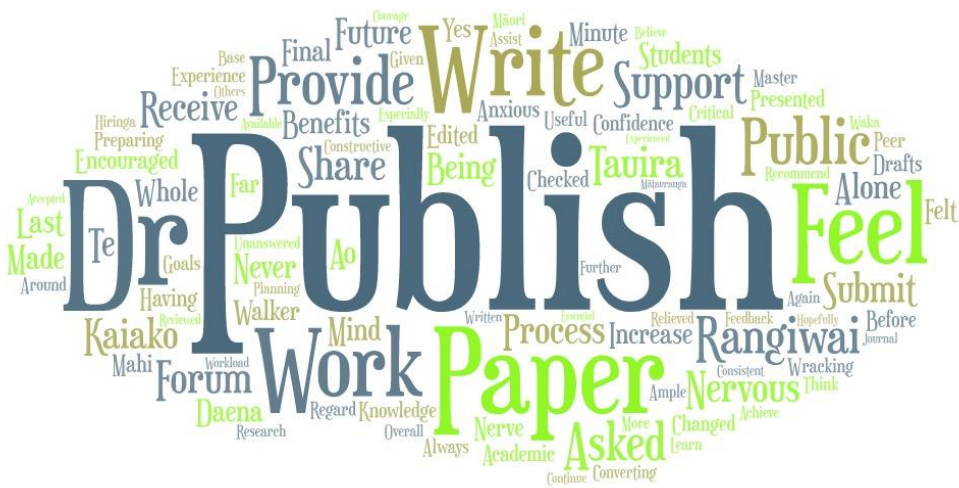

Image 4: Word Cloud based on Daena Walker's interview

\section{Rosalie Leuluai}

1) How did you feel about being asked to publish a paper?

I felt very proud about being asked to publish a paper. I had read published articles from other tauira in my class and I was really impressed by their writing. I was excited that Dr Rangiwai thought my writing good 
enough to be published. Dr Rangiwai encouraged me and told me that what I had to write was important for others to read (R. Leuluai, personal communication, 3 October 2019).

\section{2) What would you like to share about the experience of preparing a paper for publication?}

Preparing a paper for publishing is a lot of work if you have not done it before. Checking for grammar, spelling, complete sentences-as I tend to write as I would speak-and APA referencing. It felt like another assignment, only more intense because someone else in the world other than Dr Rangiwai is going to be able to read my work ( $R$. Leuluai, personal communication, 3 October 2019).

\section{3) What was your process for converting your} master's paper into a paper for publication?

"I sent my paper to Dr Rangiwai and he provided critical feedback and advice" (R. Leuluai, personal communication, 3 October 2019).

\section{4) What support did you receive from your kaiako?}

Dr Rangiwai was very encouraging. He provided many examples of his own published work to read. Dr Rangiwai was very enthusiastic about the power of publishing. He talked about how learning new things excited him and motivated him to write more articles. Dr Rangiwai was an example to us all, while his belief in our abilities as students, built up our academic confidence (R. Leuluai, personal communication, 3 October 2019).

\section{5) What further support could have been provided?}

"Dr Rangiwai went over, and beyond his duty of care and responsibility with regard to coaching and 
supervising us and encouraging the publication of our work" (R. Leuluai, personal communication, 3 October 2019).

\section{6) How did you feel when your paper was published?}

When I published my first article, I was inwardly pleased, that was until my sister's friend asked if I had written the article she was reading-I immediately felt awkward and embarrassed. I was concerned about her thoughts about what I had written and whether they were worthy of being a contributing voice in the arena of early childhood education from a Kaupapa Māori perspective. After my initial anxiety about my paper, I came to realise that my publication was a contribution to knowledge about Kaupapa Māori understandings of early childhood education from my particular and unique perspective (R. Leuluai, personal communication, 3 October 2019).

\section{7) What do you think are the benefits of} publishing for He Waka Hiringa students?

I think the benefits of publishing as a He Waka Hiringa student gives us confidence, self-belief and adds to the Indigenous narratives nationally and internationally. By publishing, we are adding to the kôrero of our fellow Indigenous peoples and in this way we are sharing and helping one another (R. Leuluai, personal communication, 3 October 2019).

\section{8) What benefits have you experienced so far from publishing?}

My level of self-confidence in my expertise as an early childhood educator has increased significantly. Since publishing my article, it seems that other educators have become interested in my paper and in my approach to early childhood education. I have been asked to share the Pedagogy of Peace that I have 
developed as my project for my master's as well (R. Leuluai, personal communication, 3 October 2019).

\section{9) Would you publish again and why? Or why not?}

"I feel better knowing I have more than one published article. My confidence is growing, so I would probably publish again" (R. Leuluai, personal communication, 3 October 2019).

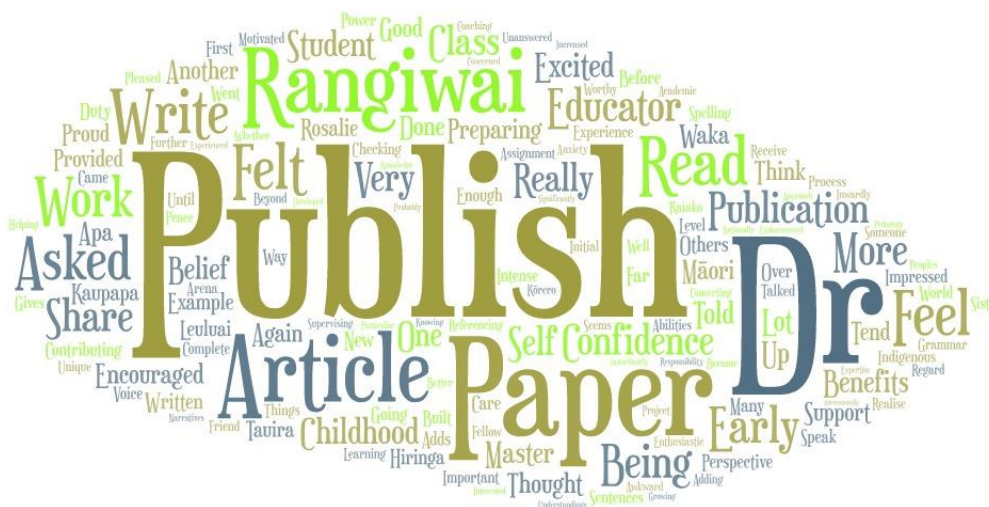

Image 5: Word Cloud based on Rosalie Leuluai's interview

\section{Latoia Sasa-Tepania}

1) How did you feel about being asked to publish a paper?

Publishing a paper was new to me. I never would have thought I would have any academic writing published in this lifetime. I am glad Dr Rangiwai presented this opportunity to us as publishing means that my work will be here, accessible, long after I am gone (L. SasaTepania, personal communication, 2 October 2019). 


\section{2) What would you like to share about the experience of preparing a paper for publication?}

Preparing a paper for a scholarly journal is difficult. However, knowing the paper we produce is our own work and our own practice gave me a sense of confidence because I know what I know and that is exactly what I was writing about in my paper-my knowledge and experiences. Being confident in the knowledge of my practice was settling and helped me to prepare for publication. I became more comfortable with the process of writing, receiving feedback from Dr Rangiwai, and having my writing subjected to peerreview and publication in the journal. I did have doubts about my work, but knowing that my practice and knowledge is something that I live, gave me confidence in who I am and what I do (L. Sasa-Tepania, personal communication, 2 October 2019).

3) What was your process for converting your master's paper into a paper for publication?

"Dr Rangiwai helped me to adapt my master's papers into articles. He checked the articles and gave me critical feedback. Dr Rangiwai sent the articles to the editor of the journal on my behalf" (L. Sasa-Tepania, personal communication, 2 October 2019).

4) What support did you receive from your kaiako?

"Dr Rangiwai provided lots of support, including: email check-ins, one-on-one support, feedback on my writing, publishing support-talking me through the process, monthly supervision catch-ups" (L. Sasa-Tepania, personal communication, 2 October 2019).

5) What further support could have been provided?

"Nil. No further support was needed" (L. Sasa-Tepania, personal communication, 2 October 2019). 


\section{6) How did you feel when your paper was published?}

"Feelings of accomplishment as though I had reached another level in my studies. None of my family has ever had anything published before. I felt like I achieved and put my family on the map" (L. Sasa-Tepania, personal communication, 2 October 2019).

7) What do you think are the benefits of publishing for He Waka Hiringa students?

"My work will live on long after I am gone. I live on in my publications" (L. Sasa-Tepania, personal communication, 2 October 2019).

8) What benefits have you experienced so far from publishing?

I am able to show my students my published works and be a role model for academic success-showing them that if I can do it, they can do it too. I am able to use published material as support in my workshops with staff to show them that I am not only a pretty face who is loud and likes to have fun at work, but that I know my stuff and I am damn good at it! (L. Sasa-Tepania, personal communication, 2 October 2019).

\section{9) Would you publish again and why? Or why not?}

"I would love to publish again in hopes my work, whatever it may be, reaches distant lands and sparksup the minds of those who will take over the world" (L. Sasa-Tepania, personal communication, 2 October 2019). 


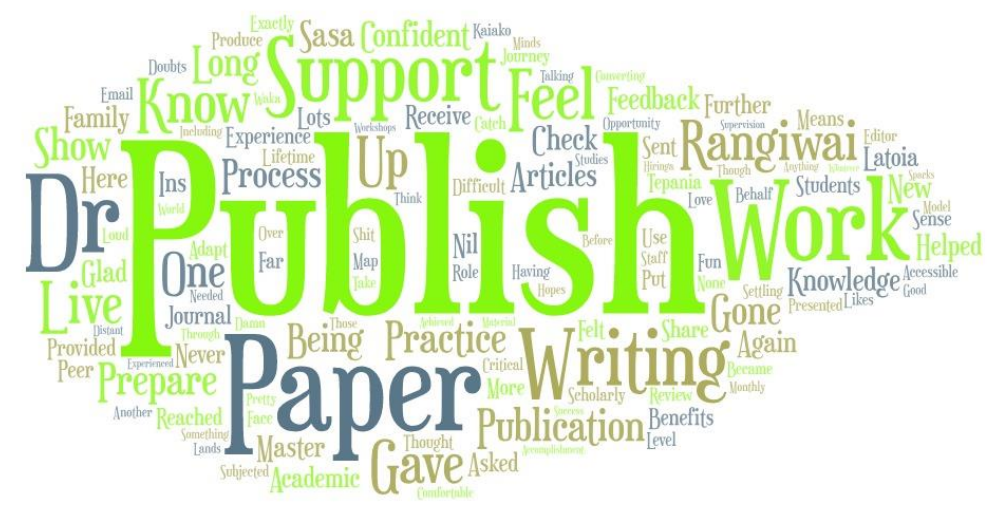

Image 6: Word Cloud based on Latoia Sasa-Tepania's interview

\section{Kane Milne}

\section{1) How did you feel about being asked to publish} a paper?

"I was honoured when Dr Rangiwai asked me, but a bit apprehensive as well. Is my writing good enough? Is it worth reading?" (K. Milne, personal communication, 3 October 2019).

2) What would you like to share about the experience of preparing a paper for publication? It was not as hard as I thought, and it helped to read other published papers on Te Kaharoa as there are a number of different writing styles. When I did that, I did not feel so constrained by any ideas that I had to strictly conform to a certain style (K. Milne, personal communication, 3 October 2019).

3) What was your process for converting your master's paper into a paper for publication? 
"I did not do too much actually. Just a few things needed changing and I had to check references" (K. Milne, personal communication, 3 October 2019).

\section{4) What support did you receive from your} kaiako?

The offer to submit came over a holiday period for me. Dr Rangiwai pushed our class to extend ourselves and produce high quality work. The offer-and in my mind, expectation-for me to produce something for publication was the push I needed at that time (K. Milne, personal communication, 3 October 2019).

\section{5) What further support could have been provided? \\ "None for me" (K. Milne, personal communication, 3 October 2019).}

\section{6) How did you feel when your paper was}

\section{published?}

"Pretty proud to be honest, and surprised it was published as quick as it was" (K. Milne, personal communication, 3 October 2019).

\section{7) What do you think are the benefits of publishing for He Waka Hiringa students?}

Just showing that your work is worthy is a huge confidence builder. A different benefit is being able to read the work of classmates. We do not get to see their writing normally, so this was awesome, and I was even able to use their publications as references in my exegesis (K. Milne, personal communication, 3 October 2019).

\section{8) What benefits have you experienced so far from publishing?}

"None directly, as yet, but a kūmara does not sing, so they say. Well, some do" (K. Milne, personal communication, 3 October 2019). 


\section{9) Would you publish again and why? Or why not?}

Yes, definitely, for a few reasons. I feel like I need to keep pushing myself and bettering my writing. I want it to be a part of my practice. I think when I do look at higher levels of study, it will be great collateral (K. Milne, personal communication, 3 October 2019).

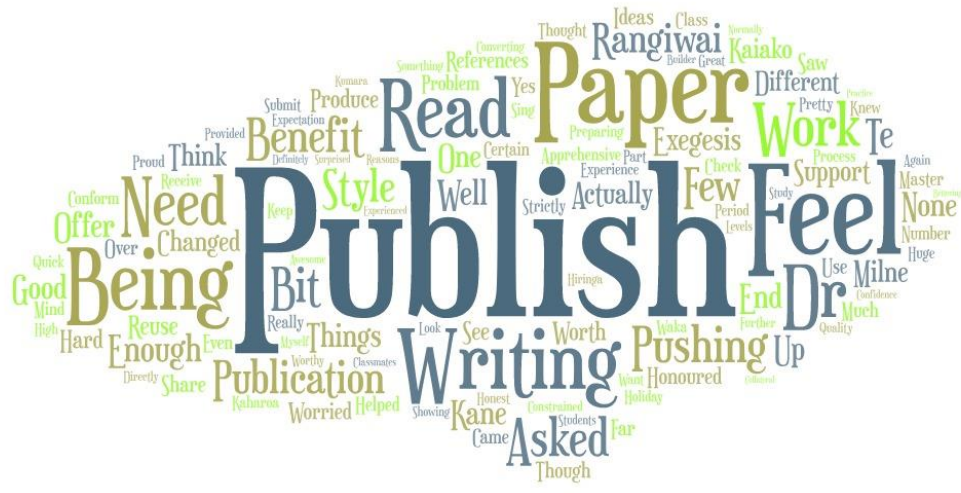

Image 7: Word Cloud based on Kane Milne's interview

\section{Fritz Filisi}

\section{1) How did you feel about being asked to publish a paper?}

I felt very privileged when Dr Rangiwai asked me to consider publishing a paper. I felt valued and appreciated. Dr Rangiwai recognised that my work needed to reach a broad audience and so he encouraged me to publish with Te Kaharoa. We discussed my paper and I decided that the Indigenous knowledge in my paper needed to be shared with the world. Dr Rangiwai's encouragement showed that he was confident in my ability to produce quality articles about my Samoan perspective (F. Filisi, personal communication, 4 October 2019). 


\section{2) What would you like to share about the experience of preparing a paper for publication?}

The experience of preparing a paper for publication was a difficult one. It required structure, discipline, time management, research, writing, proof reading, and a lot of editing. Fortunately, my wife-who writes and publishes work too-read through my drafts and challenged my thinking and approach to writing. Also, Dr Rangiwai was an excellent supervisor in both my publishing work and also in terms of my exegesis (F. Filisi, personal communication, 4 October 2019).

3) What was your process for converting your master's paper into a paper for publication?

A lot of writing and reading, proof reading and regular supervision with Dr Rangiwai. Checking with my family-especially the leaders-to ensure that they were happy with the content. Through the development of my 'Tautua a le Niu' model of practice-featured in my first publication in Te Kaharoa-I sought the blessings of my family and Atua. I received my family's blessing and I believe my Atua is also pleased with me (F. Filisi, personal communication, 4 October 2019).

\section{4) What support did you receive from your kaiako?}

Dr Rangiwai provided me with regular supervision meetings and checked the content of my article. He encouraged me to publish and pushed me to reach new heights. He constantly checked-in with me through email and face-to-face meetings. Dr Rangiwai's encouragement and support-coupled with my hard work and determination and the support of my familywere significant contributing factors to my success ( $F$. Filisi, personal communication, 4 October 2019). 


\section{5) What further support could have been} provided?

"I feel that I received so much support from Dr Rangiwai. His encouragement and support in terms of me publishing was more than I had expected from $\mathrm{He}$ Waka Hiringa" (F. Filisi, personal communication, 4 October 2019).

\section{6) How did you feel when your paper was published?}

"I was very proud when my papers were published.

Though I have published books in Samoan, this was the first time that I had published in a peer-reviewed journal" (F. Filisi, personal communication, 4 October 2019).

\section{7) What do you think are the benefits of publishing for He Waka Hiringa students?}

Publishing as a student meant that I built up what Dr Rangiwai called "academic currency" while I studied. It has meant too that I can reference my fellow student publishers. I recommend publishing work as a master's student. As He Waka Hiringa students, we come into this course as experts or practitioners in our respective fields; publishing further adds to our expertise and contributes to Indigenous knowledge in the world. In fact, we are building up Indigenous knowledge that will benefit communities here and overseas (F. Filisi, personal communication, 4 October 2019).

\section{8) What benefits have you experienced so far from publishing?}

I am able to share my publications with those want to them read by providing a link to Te Kaharoa. This means that my relatives can access my work from wherever they are, even from a smart phone. Publishing gave me a sense of achievement during my master's journey and it gave me the confidence to continue to write my master's exegesis and execute my community 
project (F. Filisi, personal communication, 4 October 2019).

\section{9) Would you publish again and why? Or why not?}

"I would publish again because I believe I am contributing to my community" (F. Filisi, personal communication, 4 October 2019).

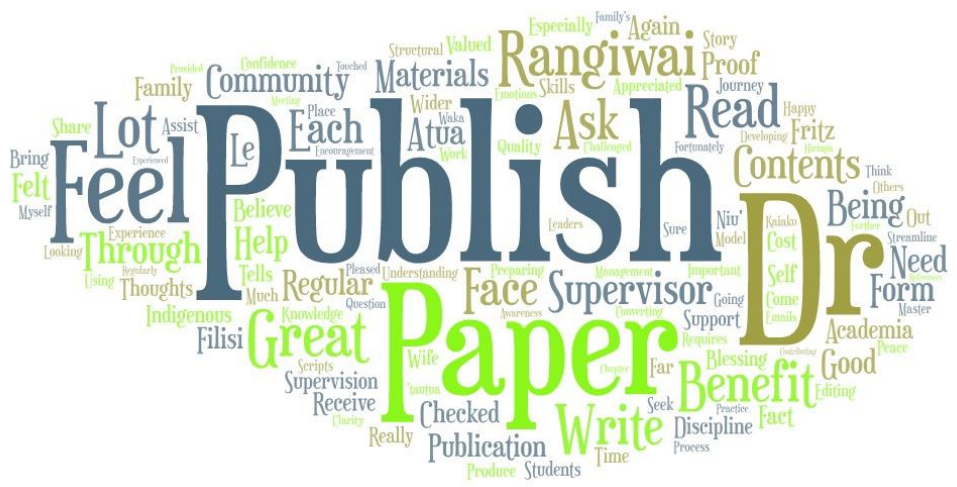

Image 8: Word Cloud based on Fritz Filisi's interview

\section{Vania Hotereni}

1) How did you feel about being asked to publish a paper?

I was surprised to be asked by Dr Rangiwai to publish as I did not expect to have this experience as part of the course. It was a challenge to be asked to publishing anything. The experience is exciting but I also experienced doubt as to whether the work produced is good enough for others to read (V. Hotereni, personal communication, 4 October 2019). 


\section{2) What would you like to share about the experience of preparing a paper for publication?}

The main challenge was making sure that I was able to reference the right information and credit to those who have written on the subject of Te Ao Māori. I know what I know, but I needed to ensure that what others know was acknowledged properly (V. Hotereni, personal communication, 4 October 2019).

3) What was your process for converting your master's paper into a paper for publication?

"My process was to consult with my supervisor, Dr Rangiwai. He guided and directed me and sent my paper off for publishing when it was ready" (V. Hotereni, personal communication, 4 October 2019).

\section{4) What support did you receive from your} kaiako?

"Dr Rangiwai was very supportive. The master's required a high level of competence and so on top of managing our regular learning, he also pushed us to publish. It was quite demanding at times, but the potential rewards of publishing were too great to refuse" (V. Hotereni, personal communication, 4 October 2019).

\section{5) What further support could have been provided?}

"No further support was needed. Dr Rangiwai provided more than enough support and insisted that we contact him if needed" (V. Hotereni, personal communication, 4 October 2019).

\section{6) How did you feel when your paper was} published?

"My whānau were more excited than me and very proud" (V. Hotereni, personal communication, 4 October 2019). 


\section{7) What do you think are the benefits of publishing for He Waka Hiringa students?}

I think it is very important to have this opportunity. Dr Rangiwai offered the chance for us to publish and we took it. It is also about the experience and emotions that you go through. More importantly, it is also about leaving a bit of knowledge behind, so that others can learn and extend their own learning. It is a personal journey (V. Hotereni, personal communication, 4 October 2019).

\section{8) What benefits have you experienced so far from publishing?}

I have received job opportunities within the organisation I work for. Publishing has given me even more credibility as a practitioner and has allowed me to input into Maori Strategies in terms of implementing Te Ao Māori processes into social work practice (V. Hotereni, personal communication, 4 October 2019).

\section{9) Would you publish again and why? Or why not?}

"Yes I would. Publishing has been a new experience for me, one that I would not have experience without $\mathrm{He}$ Waka Hiringa and, in particular, Dr Rangiwai's support (V. Hotereni, personal communication, 4 October 2019). 


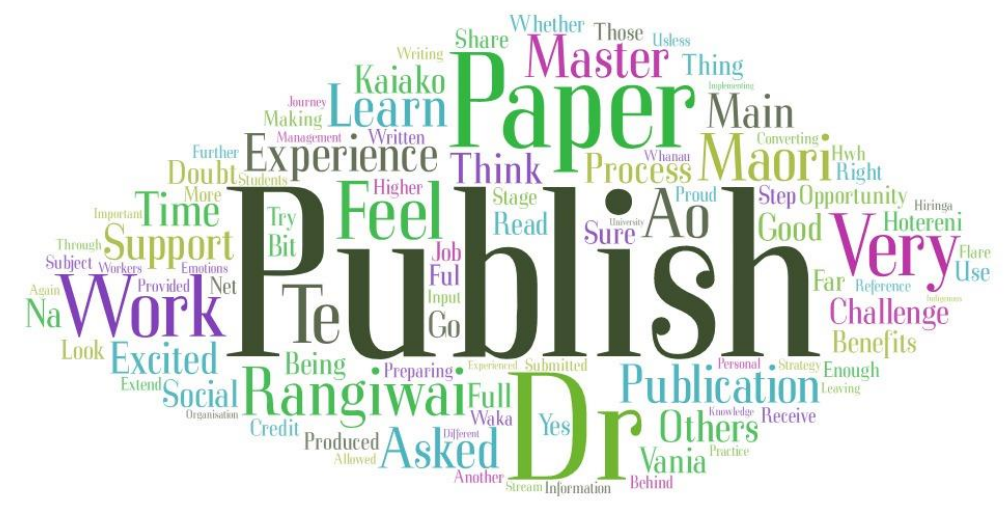

Image 9: Word Cloud based on Vania Hotereni's interview

\section{Themes from the interviews}

Three themes emerged from the interviews as follows:

- Student potential

- Kaiako supervision

- Contributing to Indigenous knowledge

\section{Student potential}

The students spoke about how they did not expect publication to be part of their master's experience. Although some students doubted their abilities at first, there was a general consensus that being asked by me to consider preparing master's papers for publication was a motivating factor as they felt my confidence in them meant that their work was "worthy" of consideration, peer-review and publication.

\section{Kaiako supervision}

The students indicated that my supervision of their publishing experience was motivational and that 
without kaiako supervision, support and encouragement, publishing would not have been possible. The mentoring received by students allowed them to confidently and courageously publish their work as significant, meaningful contributions to Indigenous knowledge.

\section{Contributing to Indigenous Knowledge}

The importance of contributing to Indigenous knowledge was expressed strongly by the students. They articulated their desires to share knowledge with the world through publishing and acknowledged that their contributions would benefit Indigenous communities looking for writing by other Indigenous scholars.

\section{Specific benefits generated for Master of Applied Indigenous Knowledge students who published}

The specific benefits experienced by students included the following:

- Increased confidence and self-belief

- Elevated sense of expertise in respective field of practice

- Enlarged sense of success as a student and practitioner

- A strong sense of contributing to Indigenous knowledge that will benefit others

\section{Increased confidence and self-belief}

The students strongly expressed that publishing generated an increased sense of confidence and selfbelief. Understanding that their writing was peerreviewed by Te Kaharoa gave them a sense that their writing was "worthy" for publication, as peer-reviewers had read their work and deemed it publishable. 


\section{Elevated sense of expertise in respective field of practice}

The students indicated that they experienced an elevated sense of expertise in their respective fields of practice. The process of publishing which included peerreviewing gave them a sense of being an authority on their ideas, knowledge, experiences, and writing. Understanding that their ideas were accessible nationally and internationally, and subject to critique and debate, added to their sense of being experts in what they know and understand from their unique perspectives.

\section{Enlarged sense of success as a student and practitioner}

The students expressed an enlarged sense of success as both student and practitioner. On the one hand, they exceeded their own expectations by publishing as master's students. On the other hand, they increased their credibility as practitioners by creating and publishing academic currency/collateral which may be openly accessed and critiqued by others. Adding to their sense of success is the fact that their publications contribute to Indigenous knowledge.

\section{A strong sense of contributing to Indigenous knowledge that will benefit others}

The students indicated a strong sense of contributing to Indigenous knowledge that will benefit others. The articles that the students published are important, meaningful and internationally available contributions to Indigenous knowledge that can be accessed from anywhere with an internet connection. This is highly significant because it means that the students exposed their knowledge to the world, 
contributed to the Indigenous archive of knowledge, and provided scholarly pathways for other Indigenous scholars to follow.

\section{Conclusion}

This paper identified the benefits for Master of Applied Indigenous Knowledge students from Te Wānanga o Aotearoa publishing their work in Te Kaharoa: The eJournal on Indigenous Pacific Issues. This paper argued that publishing in a peer-reviewed journal generated benefits for Indigenous communities and themselves. This paper showed that Master of Applied Indigenous Knowledge Students who want to publish their work need to have their potential recognised by a kaiako/supervior, be encouraged and supported by a kaiako/supervisor, and be motivated by the fact that their writing will be an important and meaningful contribution to Indigenous knowledge that will benefit other Indigenous scholars. This paper also showed that the students received particular benefits from publishing including an increased sense of confidence and self-belief, an elevated sense of expertise in their respective fields of practice, an enlarged sense of success as students and practitioners, and a strong sense of contributing to Indigenous knowledge. The importance of writing/righting the world through publishing cannot be over-emphasised. As Indigenous scholars, it is our duty to carve out space for our voices and publishing in journals is a significant way of doing this. 


\section{References}

Collins, J. C. (2015). Writing for publication while in Graduate School: An accessible reality. New Horizons in Adult Education \& Human Resource Development, 27(1), 51-55.

Cooper, T. (2016). Popular programme touch to master. Te Wānanga o Aotearoa. Retrieved from: https://www.twoa.ac.nz/Hononga-StayConnected/News-Events/2016/08/15/Popularprogramme-tough-to-Master

Kamler, B. (2008). Rethinking doctoral publication practices: Writing from and beyond the thesis. Studies in Higher Education, 33(3), 283-294.

Lee, A., \& Kamler, B. (2008). Bridging the pedagogy to doctoral publishing. Teaching in Higher Education, 13(5), 511-523.

Macauley, P., \& Green, R. (2007). Supervising publishing from the doctorate. In C. Denholm \& T. Evans (Eds.), Supervising doctorates down under: Keys to effective supervision in Australia and New Zealand (pp. 192-199). Melbourne: ACER Press.

Milne, K. (2019). Explorations of the term 'Indigenous'. Te Kaharoa: The eJournal on Indigenous Pacific Issues, 12(1), 1-11. Retrieved from: https://www.tekaharoa.com/index.php/tekaharo a/article/view/262

Nackoney, C.K., Munn, S.L., \& Fernandez, J. (2011). Learning to write: Wisdom from emerging scholars. In T.S. Rocco \& T. Hatcher (Eds.), The handbook of scholarly writing and publishing (pp. 26-43). San Francisco, CA: Wiley.

Pickering, C. \& Byrne, J. (2013). The benefits of publishing systematic quantitative literature reviews for $\mathrm{PhD}$ candidates and other early-career researchers. Higher Education Research \& Development, 33(3), 534-548.

Preacher, K. J. (2003). Publishing in Graduate School: Tips for new graduate students. Retrieved from: https://www.psychologicalscience.org/observer/p 
ublishing-in-graduate-school-tips-for-newgraduate-students- 2

Rich, T. (2013). Publishing as a graduate student: A quick and (hopefully) painless guide to establishing yourself as a scholar. Political Science and Politics, 46(2), 376-379.

Te Wānanga o Aotearoa (n.d.). He Waka Hiringa: Master of Applied Indigenous Knowledge. Retrieved from: https://www.twoa.ac.nz/Nga-Akoranga-OurProgrammes/Education/Master-of-AppliedIndigenous-Knowledge-Education

Te Wānanga o Aotearoa (2019). He Waka Hiringa: Master of Applied Indigenous Knowledge, MAIK801 \& 901, Marau 2019. Retrieved from:

https://twoa.sharepoint.com/sites/teams/marau centre/MarauActive/MAIK801-

901\%20He\%20Waka\%20Hiringa\%20Marau\%2020 $19 \% 20(002) \cdot \mathrm{pdf}$

Trammell, A. (2014). The benefits of publishing as an undergraduate. Retrieved from: https://publish.illinois.edu/ugresearch/2014/10 / 14/the-benefits-of-publishing-as-anundergraduate/

Van Cott, D. L. (2005). A graduate student's guide to publishing scholarly journal articles. Political Science and Politics, 38(4), 741-743. 